\title{
Effect of liquid volume and microflora source on degradation rate and microbial community in corn stover degradation
}

\author{
Jingjing Wang ${ }^{1,2^{*}+} \odot$, Dan Zhu ${ }^{1,2+}$, Siqi Zhao ${ }^{1,2}$, Song $X u^{1,2}$, Rong Yang ${ }^{1,2}$, Wei Zhao ${ }^{1,2}$, Xiaoxia Zhang ${ }^{1,2}$ and \\ Zhiyong Huang ${ }^{1,2}$
}

\begin{abstract}
Degradation is the bottleneck in the utilization of crop straw. In this paper, we screened the microbial consortia degrading corn stover from straw degrading consortia $M C 1(M)$, sheep feces $(Y)$, and mixtures $(Q)$ of $M$, $Y$, and cattle feces. The effects of microflora source and liquid volume (representing dissolved oxygen) on the microbial community and degradation rate of corn stover were investigated. The results showed that the degradation rate and cellulase activity of a $200 \mathrm{~mL}$ liquid volume (L2) were significantly higher than that of $100 \mathrm{~mL}$ (L1). Microflora source had a significant effect on bacterial and fungal diversity, composition and taxa. $Q$ and $Y$ had higher bacterial and fungal a-diversity than that of $\mathrm{M}$. The degradation rate was significantly correlated with cellulase activity but not with microbial diversity. This indicated that liquid volume had a significant effect on degradation rate while microflora source had a significant effect on microbial community in corn stover degradation.
\end{abstract}

Keywords: Corn stover degradation, Microbial consortia, Microbial diversity, Dissolved oxygen, Cellulase

\section{Key points}

- Liquid volume had a significant effect on degradation rate and cellulase activity.

- Microflora source had a significant effect on microbial community.

- The degradation rate was significantly correlated with cellulase activity.

\footnotetext{
*Correspondence: wang_jj@tib.cas.cn

†ingjing Wang and Dan Zhuab contributed equally to this study

${ }^{1}$ Tianjin Key Laboratory for Industrial Biological Systems

and Bioprocessing Engineering, Tianjin Institute of Industrial

Biotechnology, Chinese Academy of Sciences, No. 32, West 7th Avenue,

Tianjin Airport Economic Area, Tianjin 300308, P R China

Full list of author information is available at the end of the article
}

\section{Introduction}

Crop straw is the most abundant renewable biomass, and its worldwide annual yield is estimated at 200 billion tons (Liang et al. 2020). The use of crop straw as a source of energy, forage, fertilizer, and other high value chemicals is of great interest (Zhang 2008). However, due to the complexity of lignocellulose structure, degradation is the bottleneck in the utilization of crop straw. Compared with the physical and chemical degradation of straw, microbial degradation has the advantages of environmental friendliness and high efficiency (Liang et al. 2020). A number of microorganisms have been isolated and used to degrade straw (Arntzen et al. 2020; Ding et al. 2019). Under natural conditions, the degradation of straw depends on the synergistic action of multiple microorganisms (Liang et al. 2020; Wang et al. 2016). Microbial consortia can improve the efficiency and stability of straw degradation compared to a single strain (Gong et al. 2020; Zuroff and Curtis 2012). Many microbial consortia with high cellulose-degrading activity have been obtained 
by combination or domestication (Chu et al. 2021; Kato et al. 2005).

Corn stover accounts for about $25 \%$ of crop straw. There are many microbial consortia that can degrade corn stover (Table 1). Some microbial consortia can degrade more than $70 \%$ of corn stover pretreated with acid or alkali (Wongwilaiwalin et al. 2010; Zhang et al. 2018). However, this is not only expensive but also pollutes the environment. Most microbial consortia can only degrade less than $60 \%$ of corn stover without pretreatment (Yu et al. 2019; Zhang et al. 2012). Therefore, it is necessary to screen the efficient microbial consortia, which can degrade corn stover without pretreatment.

Efficient straw degrading microflora are usually obtained from ruminant feces or long-term storage of lignocellulose (Haruta et al. 2002; Liang et al. 2020). Wongwilaiwalin et al. (2013) demonstrated that the microflora sources had significant effects on degradation rate and microbial community. Xing et al. (2020) demonstrated that cow rumen microorganisms are more suitable than sheep rumen microorganisms for corn stover transformation. Efficient straw-degrading microbial consortia mostly depend on the efficient cooperation of aerobic and anaerobic bacteria (Kato et al. 2005; Zhou et al. 2015). Generally, aerobic bacteria consume oxygen and provide a suitable living environment for anaerobic bacteria. Anaerobic bacteria provide a carbon source for aerobic bacteria, mainly by degrading lignocellulose. Some literature has shown that oxygen significantly affects the efficiency of straw degradation (Lu et al. 2008; Wang et al. 2004). However, the effect of oxygen on the microbial community for corn stover degradation has not been reported.

In this paper, we used the domestication method to screen the microbial consortia that can efficiently degrade corn stover without pretreatment from different environments and studied the effects of microflora source and dissolved oxygen (reflected by liquid volume)

Table 1 Microbial consortia degrading corn stover

\begin{tabular}{|c|c|c|c|c|c|c|}
\hline Microbial Consortia & Temperature $\left({ }^{\circ} \mathrm{C}\right)$ & Speed (rpm) & Pretreated & $\begin{array}{l}\text { Degradation } \\
\text { ratio }(\%)\end{array}$ & Time (days) & Reference \\
\hline $\begin{array}{l}\text { CDS-10, enriched from rotten } \\
\text { animal manure and corn } \\
\text { straw }\end{array}$ & 25 & 180 & $1.5 \% \mathrm{H}_{2} \mathrm{SO}_{4}$ & 63.09 & 15 & (Tang et al. 2020) \\
\hline $\begin{array}{l}\text { Consisting of Pelomonas gx. } \\
\text { and Curvibacter zj. }\end{array}$ & 35 & 120 & $10 \% \mathrm{NaOH}$ & 78.10 & 15 & (Zhang et al. 2018) \\
\hline Enriched from corn field soil & 30 & 0 & $1.5 \% \mathrm{NaOH}$ & 66.1 & 10 & (Deng et al. 2017) \\
\hline $\begin{array}{l}\text { BGC-1, enriched from indus- } \\
\text { trial sugarcane bagasse pile }\end{array}$ & 50 & 200 & $10 \% \mathrm{NaOH}$ & 72 & 4 & (Wongwilaiwalin et al. 2013) \\
\hline $\begin{array}{l}\text { Enriched from feces and } \\
\text { sludge }\end{array}$ & 50 & 0 & Steam-exploded & 62 & 7 & (Zhang et al. 2012) \\
\hline $\begin{array}{l}\text { CSS-1, enriched from sugar- } \\
\text { cane bagasse compost }\end{array}$ & 50 & 0 & Alkali-peracetic acid & 70 & 7 & (Wongwilaiwalin et al. 2010) \\
\hline $\begin{array}{l}\text { Consisting of three Strepto- } \\
\text { myces }\end{array}$ & 30 & 210 & $\mathrm{NO}$ & 60.55 & 7 & (Gong et al. 2020) \\
\hline $\begin{array}{l}\text { GF-20, enriched from soil and } \\
\text { cow dung }\end{array}$ & 30 & 0 & $\mathrm{NO}$ & 59.47 & 60 & $\begin{array}{l}\text { (Qinggeer et al. 2016; Yu et al. } \\
\text { 2019) }\end{array}$ \\
\hline $\begin{array}{l}\text { Consisting of Pelomonas gx. } \\
\text { and Curvibacter zj. }\end{array}$ & 35 & 120 & $\mathrm{NO}$ & 58 & 15 & (Zhang et al. 2018) \\
\hline $\begin{array}{l}\text { Enriched from the soil of a } \\
\text { cattle and chicken manure } \\
\text { storage tank }\end{array}$ & $28-32$ & 80 & $\mathrm{NO}$ & 48.52 & 6 & (Wang et al. 2014) \\
\hline $\begin{array}{l}\text { Enriched from feces and } \\
\text { sludge }\end{array}$ & 50 & 0 & $\mathrm{NO}$ & 51 & 7 & (Zhang et al. 2012) \\
\hline $\begin{array}{l}\text { Enriched from straw accumu- } \\
\text { lation soil and rotten straw }\end{array}$ & 37 & 0 & $\mathrm{NO}$ & 40 & 50 & (Qiao et al. 2013) \\
\hline MC1, enriched from compost & 55 & 0 & $\mathrm{NO}$ & 59 & 14 & $\begin{array}{l}\text { (Cui et al. 2002; Yuan et al. } \\
\text { 2011) }\end{array}$ \\
\hline $\begin{array}{l}\mathrm{H}-\mathrm{C} \text {, enriched from wood- } \\
\text { lands soil }\end{array}$ & 40 & 0 & $\mathrm{NO}$ & 51 & 8 & (Feng et al. 2011) \\
\hline $\begin{array}{l}\text { CSS-1, enriched from sugar- } \\
\text { cane bagasse compost }\end{array}$ & 50 & 0 & $\mathrm{NO}$ & 62 & 7 & (Wongwilaiwalin et al. 2010) \\
\hline $\begin{array}{l}\text { CSS-1, enriched from corn } \\
\text { field soil }\end{array}$ & 30 & 0 & $\mathrm{NO}$ & 40.9 & 16 & (Liu et al. 2010) \\
\hline
\end{tabular}


on the degradation rate and microbial community of corn stover. This can not only provide guidance for screening efficient straw degradation community but also lay a foundation for mechanism analysis of microbial community degradation of corn stover.

\section{Materials and methods \\ Materials}

Sources of microflora for the preparation of microbial consortia in this study were collected from (1) MC1, which was domesticated to degrade rice straw (Haruta et al. 2002), (2) sheep feces from a sheep farm (Shijiazhuang, China), and (3) cattle feces from a cow farm (Shijiazhuang, China). Chopped corn stover (the length was about $2-10 \mathrm{~cm}$, and the width was about $0.2-2 \mathrm{~cm}$ ) was obtained from Jilin, China.

Construction of microbial consortia degrading corn stover Ten grams (or $10 \mathrm{~mL}$ ) of MC- 1 , sheep feces, or cattle feces was used to inoculate a $250 \mathrm{~mL}$ flask containing unsterilized $100 \mathrm{~mL}$ PCS media $(0.1 \%$ yeast extract, $0.5 \%$ peptone, $0.5 \% \mathrm{CaCO}_{3}, 0.5 \% \mathrm{NaCl}$, and $2 \%$ corn stover) (Haruta et al. 2002). The mixture was incubated at $50{ }^{\circ} \mathrm{C}$ under static conditions for 20 days, after which $10 \mathrm{~mL}$ of the culture was then transferred into fresh media. This procedure was repeated 3 times. After that, we obtained microbial consortia degrading corn stover from $\mathrm{MC1}$ $(\mathrm{M})$, sheep feces $(\mathrm{Y})$, and cattle feces $(\mathrm{N})$. Then, the three consortia were equally mixed together to obtain microbial consortia Q.

\section{Successive subcultivation of microbial consortia degrading corn stover}

Efficient microbial consortia $\mathrm{M}(\mathrm{M})$, microbial consortia $\mathrm{Q}(\mathrm{Q})$, microbial consortia $\mathrm{Y}(\mathrm{Y})$, and PCS medium (CK) were used to inoculate a $250 \mathrm{~mL}$ conical flask containing $4 \mathrm{~g}$ corn straw and $100 \mathrm{~mL}$ sterilized PCS media at $20 \%$ inoculum (L1), and then incubated for 25 days at $50{ }^{\circ} \mathrm{C}$ for 3 consecutive generations. The $20 \%$ inoculum was used to inoculate a $250 \mathrm{~mL}$ conical flask containing $4 \mathrm{~g}$ corn stover and $200 \mathrm{~mL}$ sterilized PCS media (L2), and incubated at $50{ }^{\circ} \mathrm{C}$ for 25 days. The initial surface dissolved oxygen was detected by Luminescent Dissolved Oxygen (LDO) Sensors HQ40d (HACH Company, Loveland, Colorado, USA).

\section{Determination of the degradation rate of corn stover}

The 9 samples cultured from three microbial consortia $(\mathrm{M} / \mathrm{Q} / \mathrm{Y})$ three times (3-5 generations) were shaken and filtered aseptically. The filtrate was mixed with $50 \%$ glycerin $(1: 1)$ and stored at $-80{ }^{\circ} \mathrm{C}$ for analysis. The straw residue was washed twice with $3 \%$ acetic acid and water, and then dried in an oven at $105{ }^{\circ} \mathrm{C}$ ( $\mathrm{Li}$ et al. 2020). The degradation rate was calculated by dividing the residual weight in treatments by that in CK.

\section{Analysis of cellulase activity}

Endo-glucanase (CMCase, Endo-1, 4-b-D-glucanase; EC 3.2.1.4) activity of the 9 samples was analyzed by following the method of Saini et al. (2015). Briefly, $0.5 \mathrm{~mL}$ of suitably diluted filtrates and $1 \mathrm{~mL}$ of $1 \%(\mathrm{w} / \mathrm{v}) \mathrm{CMC}$ solution in citrate buffer $(50 \mathrm{mM}, \mathrm{pH} 4.5)$ were mixed and incubated at $50{ }^{\circ} \mathrm{C}$ for $30 \mathrm{~min}$. The reaction was terminated by adding $1 \mathrm{~mL}$ of $1 \mathrm{~mol} / \mathrm{L} \mathrm{NaOH}$ solution. Then, $3 \mathrm{~mL}$ of 3,5-dinitrosalicylic acid (DNS) was added and incubated in boiling water for $10 \mathrm{~min}$. After cooling with running water, the volume was fixed to $25 \mathrm{~mL}$, and the absorbance of glucose was measured at $540 \mathrm{~nm}$. One unit (IU) of enzyme activity was defined as the amount of enzyme required to liberate $1 \mu \mathrm{mol}$ of glucose.

\section{Analysis of microbial diversity}

The filtrates of the 9 samples were used to extract DNA and sequence using bacterial (515 F: GTGCCA GCMGCCGCGGTAA; 806R: GGACTACHVGGGTWT CTAAT) and fungal (ITS5-1737 F: GGAAGTAAAAGT CGTAACAAGG; ITS2-2043R: GCTGCGTTCTTCATC GATGC) primers using the Hiseq platform by Novogen Co., Ltd (Tianjin, China). Microbial diversity analysis was performed using BMKCloud (www.biocloud.net). All statistical analyses were performed using $\mathrm{R}$ (version 3.1.1). Analysis of variance (ANOVA) was used to evaluate the effects of microflora source and liquid volume on corn stover degradation, cellulase activity, and microbial diversity. Principal coordinate analysis (PCoA) and permutational multivariate analysis of variance (PERMANOVA) with the ADONIS function based on the weighted UniFrac distance were performed to evaluate the overall differences in the bacterial community (Wang et al. 2018).

\section{Results \\ Effects of microflora source and liquid volume on corn stover degradation}

The results showed that the degradation rate of corn stover was significantly affected by liquid volume but not microflora source (Fig. 1D-F). The degradation rate of $200 \mathrm{~mL}$ liquid volume (L2) was significantly higher than that of $100 \mathrm{~mL}$ (L1) (Fig. 1F). The degradation rate of L2 was increased by $49 \%$ compared with L1, reaching $67.41 \%$ (Fig. 1F). The best degradation treatment was Y3, for which the degradation rate was $71.59 \%$ (Fig. 1D).

Effects of microflora source and liquid volume on cellulase activities

Endo-glucanase activity was significantly affected by liquid volume but not microflora source (Fig. 1G-I). The 
(A)

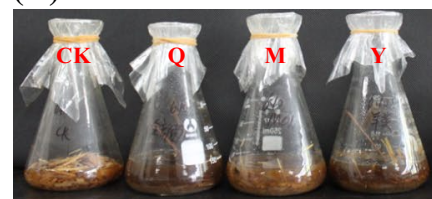

(D)

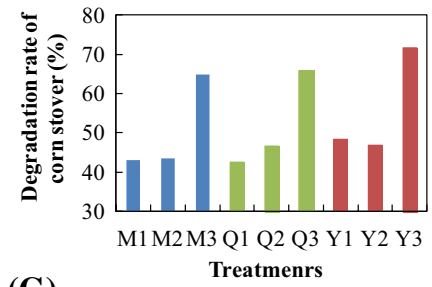

(G)

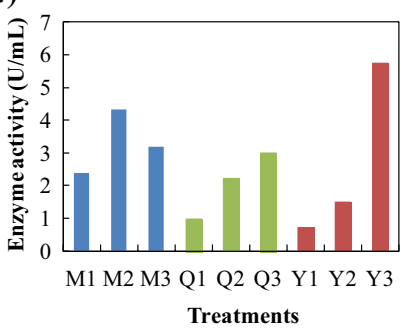

(B)

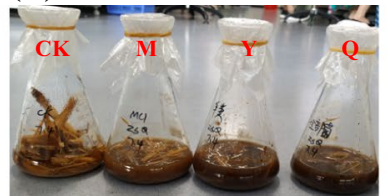

(E)

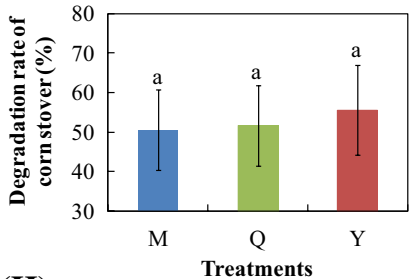

(H)

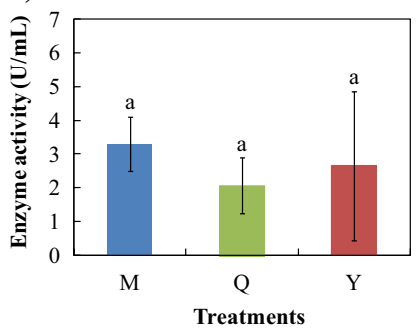

(C)

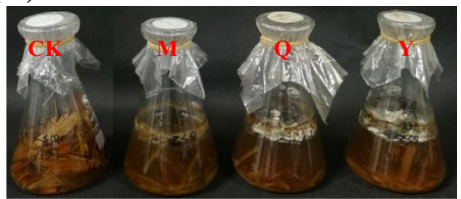

(F)

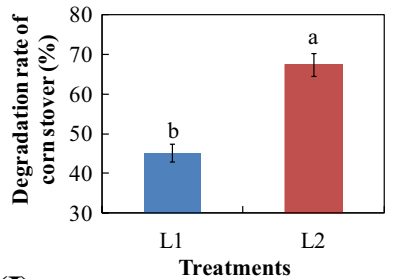

(I)

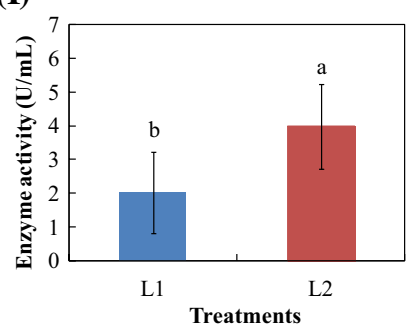

Fig. 1 Degradation experiment of the first $(\mathbf{A})$, second $(\mathbf{B})$, and third $(\mathbf{C})$ generation and the effect of treatments $(\mathbf{D} / \mathbf{G})$, microflora sources $(\mathbf{E} / \mathbf{H})$, and liquid volume (F/I) on corn stover degradation $(\mathbf{D} / \mathbf{E} / \mathbf{F})$ and endo-glucanase activity $(\mathbf{G} / \mathbf{H} / \mathbf{I})$. M, microbial consortia source from $M C 1 ;$, microbial consortia source from MC1, sheep, and cattle feces; Y, microbial consortia source from sheep feces; L1, $100 \mathrm{~mL}$ PCS medium; L2, $200 \mathrm{~mL}$ PCS medium. Values followed by different letters are significantly different at $P<0.05$

endo-glucanase of L2 was significantly increased by 2-fold compared with L1, reaching $3.98 \mathrm{U} / \mathrm{ml}$ (Fig. 1I). Pearson correlation results showed that there was a significant correlation between degradation rate and endoglucanase activity $(P<0.05)$ (Table 2$)$.

\section{Effects of microflora source and liquid volume on microbial diversity}

Across all samples, we obtained high-quality bacterial $(60,162-69,939$ sequences per sample, total $=590,998$, mean $=65,666)$ and fungal sequences $(53,598-69,121$ sequences per sample, total $=564,656$, mean $=62,740$ ). After rarefied to 49,000 sequences per sample, microbial diversity and abundance were calculated. The $\alpha$-diversity of bacteria and fungi was significantly affected by different microflora sources (Fig. 2). The bacterial Shannon index of $\mathrm{Q}$ and $\mathrm{Y}$ was significantly higher than that of $\mathrm{M}$. The fungal Shannon index of $M$ was significantly lower than that of $Q$. Liquid volume had no significant effect on microbial $\alpha$-diversity. Pearson correlation results showed that there was no significant correlation between degradation rate and microbial $\alpha$-diversity (Table 2). The results of PCoA and PERMAVONA showed that there were significant differences in bacterial and fungal communities of different microflora sources (Fig. 3A and C). The bacterial and fungal communities were not significantly affected by different liquid volumes (Fig. 3B and D).

Table 2 Pearson correlations of degradation ratio with cellulose activity and microbial diversity

\begin{tabular}{lllrr}
\hline & & Endoglucanase activity & Bacterial alpha diversity & $\begin{array}{l}\text { Fungal } \\
\text { alpha } \\
\text { diversity }\end{array}$ \\
\hline Degradation rata & Pearson correlations & $\mathbf{0 . 6 7 6}$ & 0.136 & -0.422 \\
& Significance $(P)$ & $\mathbf{0 . 0 4 6}$ & 0.728 & 0.258 \\
\hline
\end{tabular}



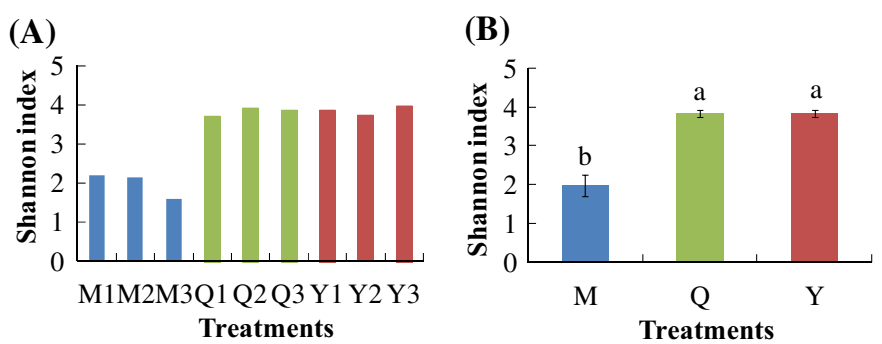

(E)

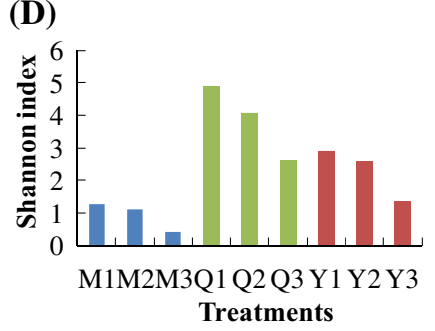

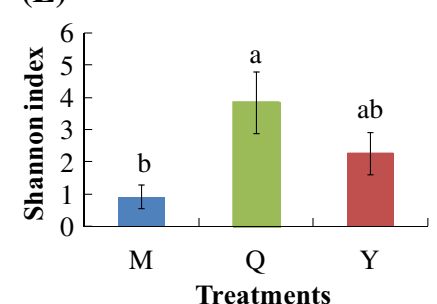

(C)

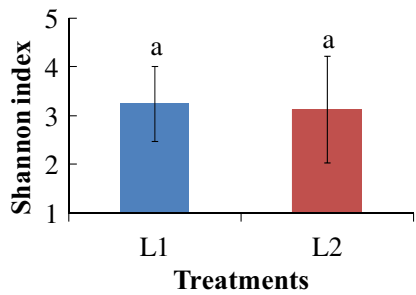

(F)

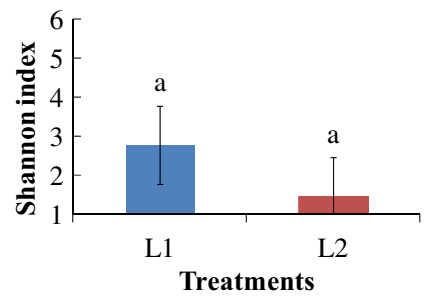

Fig. 2 Effect of treatments (A/D), microflora source (B/E), and liquid volume (C/F) on bacterial $(\mathbf{A} / \mathbf{B} / \mathbf{C})$ and fungal (D/E/F) a-diversity. M, microbial consortia source from $\mathrm{MC1}$; Q, microbial consortia source from MC1, sheep, and cattle feces; Y, microbial consortia source from sheep feces; L1, 100 mL PCS medium; L2, $200 \mathrm{~mL}$ PCS medium. Values followed by different letters are significantly different at $P<0.05$

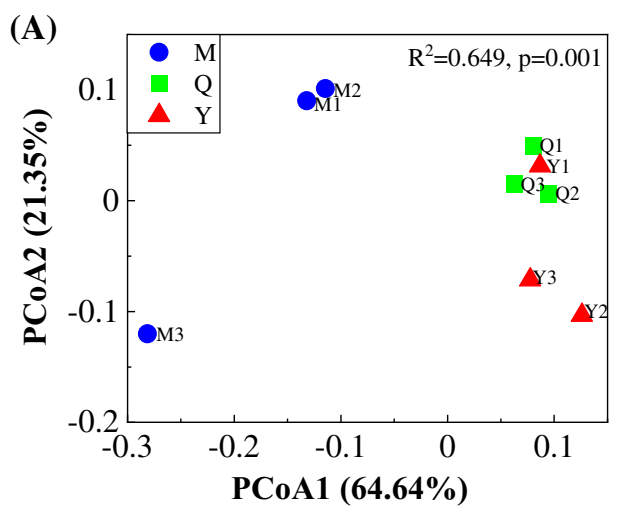

(C)

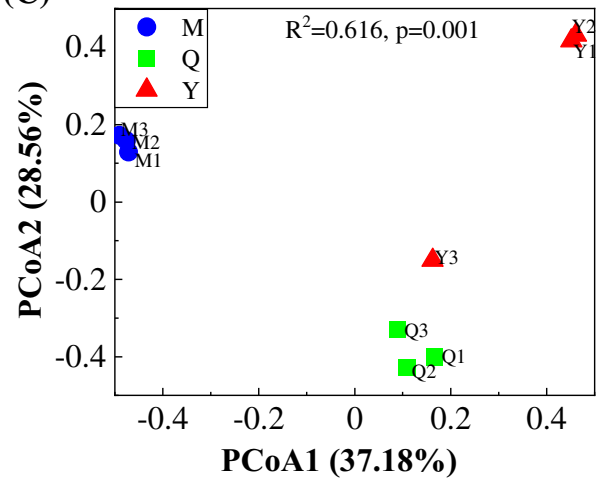

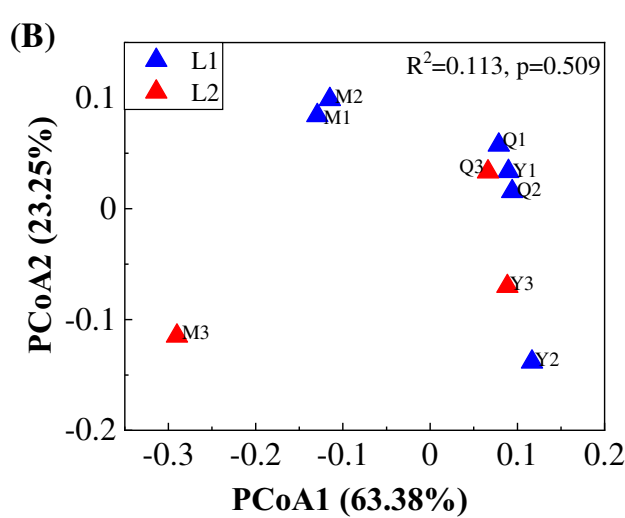

(D)

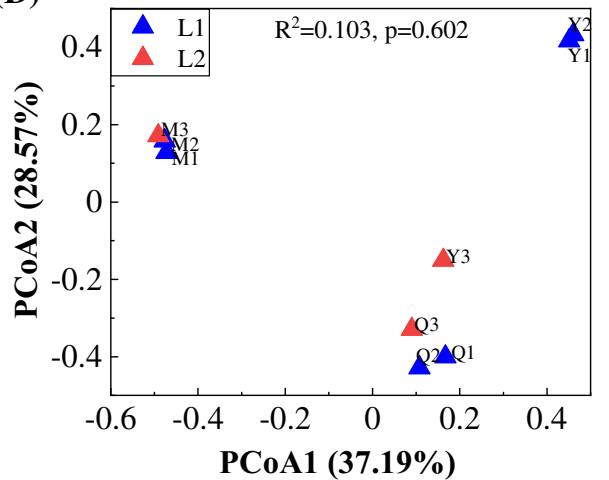

Fig. 3 Principal coordinate analysis (PCoA) of weighted UniFrac distances of the bacterial (A/B) and fungal (C/D) community under different microflora sources $(\mathbf{A} / \mathbf{C})$ and liquid volumes $(\mathbf{B} / \mathbf{D})$. M, microbial consortia source from $M C 1 ; Q$, microbial consortia source from $M C 1$, sheep, and cattle feces; Y, microbial consortia source from sheep feces; L1, $100 \mathrm{~mL}$ PCS medium; L2, $200 \mathrm{~mL}$ PCS medium 

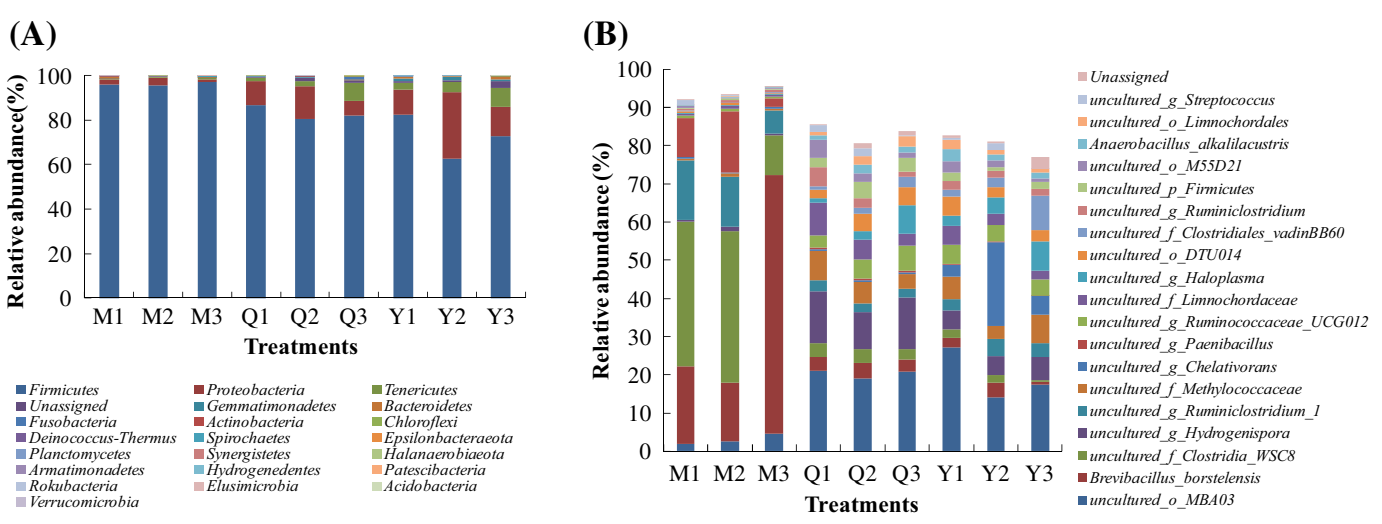

(C)

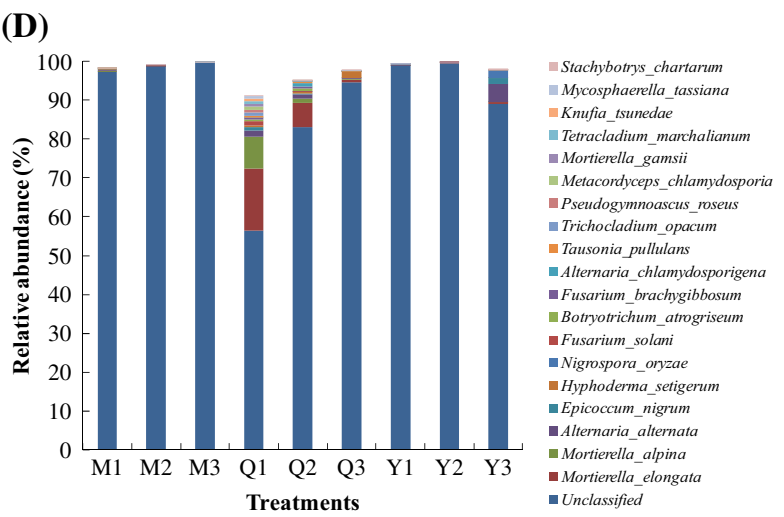

Fig. 4 The bacterial (A/B) and fungal (C/D) phyla (A/C) and top 100 species $(\mathbf{B} / \mathbf{D})$ in different treatments

Effects of microflora source and liquid volume on microbial composition

Firmicutes and Proteobacteria were the dominant bacterial phyla across all treatments (Fig. 4A). The top 5 bacterial species in $\mathrm{M}$ were Brevibacillus borstelensis, uncultured_Clostridia_WSC-8, uncultured_Ruminiclostridium_1, uncultured_Paenibacillus, and uncultured_o_MBA03. The top 5 bacterial species in $\mathrm{Q}$ were uncultured_o_MBA03, uncultured_Hydrogenispora, $\mathrm{u} \mathrm{n} \mathrm{c} \mathrm{u} \mathrm{l} \mathrm{t} \mathrm{u} \mathrm{r} \mathrm{e} \mathrm{d} L i m n o c h o r d a c e a e$, uncultured_Methylococcaceae,

and uncultured_Ruminococcacea $e_{-} \mathrm{UCG}$ 012. The top 5 species genera in $\mathrm{Y}$ were uncultured_o_MBA03, uncultured_Chelativorans, u n c u l t u r e d_. Methylococcace $a e$, uncultured_Hydrogenispora,

and uncultured_Haloplasma (Fig. 4B). Unclassified, Ascomycota, Basidiomycota, and Mortierellomycota were the dominant fungal phyla across all treatments (Fig. 4C). The top 5 fungal species in $M$ were Unclassified, Alternaria alternata, Fusarium solani, Mortierella alpine, and Malassezia restricta. The top 5 fungal species in Q were Unclassified, Mortierella elongata, Mortierella alpina, Alternaria alternata, and Hyphoderma setigerum. The top 5 fungal species in $\mathrm{Y}$ were Unclassified, Alternaria alternata, Nigrospora oryzae, Epicoccum nigrum, and Zopfiella marina (Fig. 4D).

\section{Effects of microflora source and liquid volume on microbial taxa}

LEfSe analysis showed that different microflora sources had significant effects on bacterial taxa (Fig. 5A). M enriched some bacterial taxa from Paenibacillus, Clostridiaceae_1, Ruminiclostridium_1, and M55_D21. Q enriched some bacterial taxa from Deinococcales, Sinibacillus, Heliobacteriaceae, Thermoanaerobacterales, Limnochordales, and uncultured_bacterium_p_Firmicutes. Y enriched some bacterial taxa from Dysgonomonadaceae, Thermobacillus, Caldicoprobacteraceae, Christensenellaceae, Clostridium_sensu_stricto_10, Family_XI, Ruminococcaceae_UCG_010, Ruminococcaceae_UCG_013, D8A_2, uncultured_S0134, Rhizobiales, uncultured_Alp haproteobacteria, Myxococcales, CCD24, and Izimaplasmatales. There were a few differences in bacterial taxa between different liquid volumes (Fig. 5B). L1 enriched 


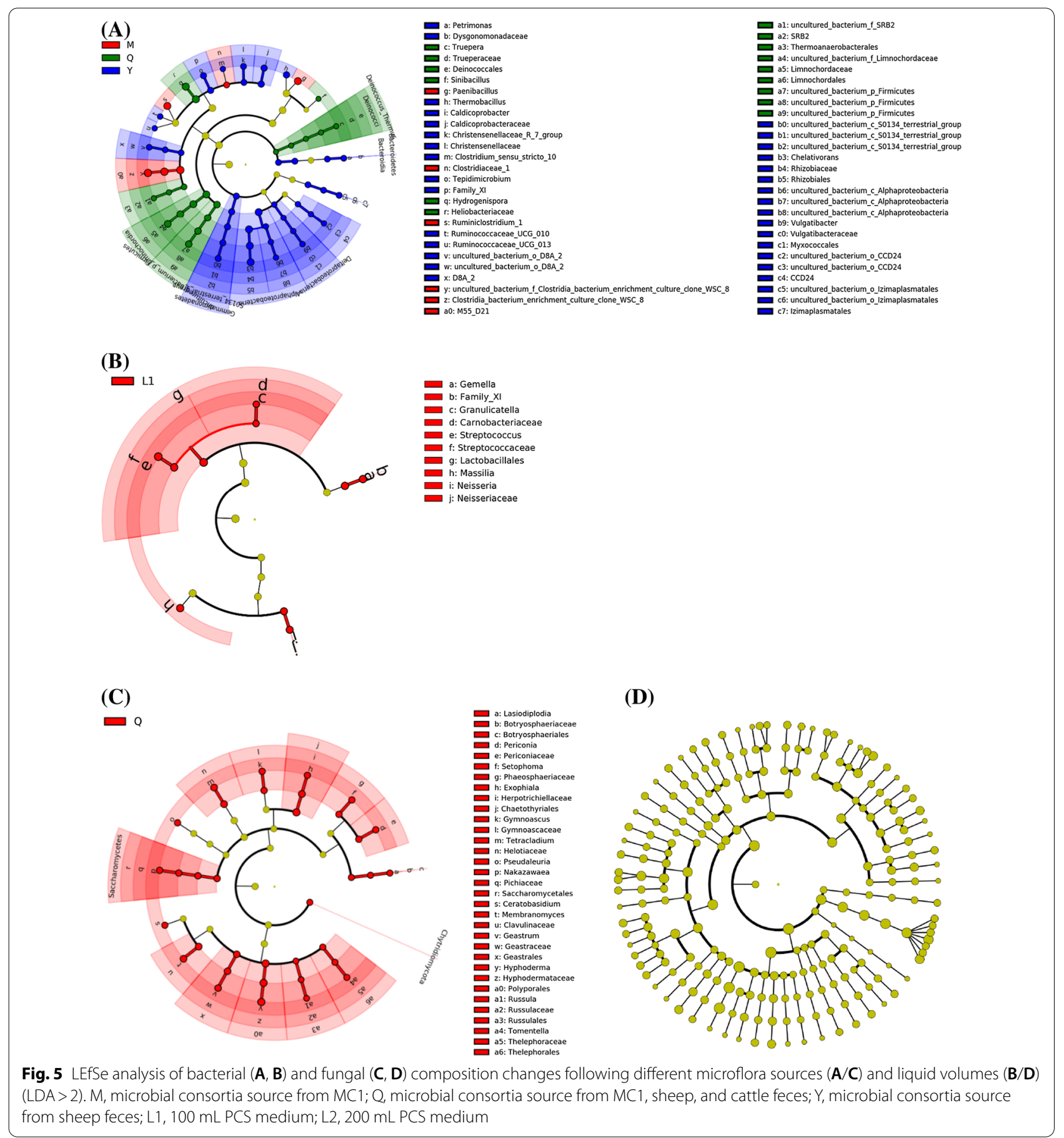

15 bacterial species from Gemella, XI, Granulicateriaceae, Streptococcaceae, Lactobacillales, Massilia, and Neisseriaceae. Different microflora sources had an effect on fungal taxa (Fig. 5C). Q enriched 44 fungal taxa from Botryosphaeriales, Periconiaceae, Phaeosphaeriaceae, Alternaria chlamydosporigena, Chaetothyriales, Gymnoascaceae, Helotiaceae, Pseudaleuria, Saccharomycetes,
Fusarium brachygibbosum, Chaetomium iranianum, Microdochium trichocladiopsis, Ceratobasidium, Clavulinaceae, Geastrales, Polyporales, Russulales, Thelephorales, Chytridiomycota, Mortierella amoeboidea, and Mortierella hyalina. There was no significant difference in fungal taxa between different liquid volumes (Fig. 5D). 


\section{Discussion}

Our study revealed that microflora source had no significant effect on corn stover degradation. However, Wongwilaiwalin et al. (2013) showed that microbial consortia enriched from industrial sugarcane bagasse pile (BGC1) had a better ability to degrade alkali pretreated corn stover $(72 \%)$ than those enriched from cow rumen fluid (CRC-1) and pulp mill-activated sludge (ASC-1). Different conclusions on degradation rate might be due to the similarity of consortia sources. All three of our microbial consortia $(\mathrm{M} / \mathrm{Q} / \mathrm{Y})$ came from feces or compost containing feces. The sources of our microbial consortia is similar, while the sources of Wongwilaiwalin's microbial consortia is different. This indicated that the ability of lignocellulose degradation rate might not be very different among the microbial consortia from similar sources.

Our study found that a higher liquid volume increased corn stover degradation. Higher liquid volume will lead to lower dissolved oxygen in the conical flask. The initial surface dissolved oxygen of L1 and L2 was 7.05 and $5.86 \mathrm{mg} / \mathrm{L}$, respectively. This indicated that straw degradation was more efficient in a lower dissolved oxygen environment. This was supported by previous works demonstrating that microbial consortia need a microaerobic environment to degrade corn stover ( $\mathrm{Lu}$ et al. 2008; Wang et al. 2004). Some reports also displayed that straw degradation was completed by aerobic and anaerobic bacteria, in which anaerobic bacteria played a role in degradation (Kato et al. 2005; Zhou et al. 2015). Therefore, we speculated that the lower dissolved oxygen environment caused by a higher liquid volume might promote the abundance or activity of anaerobic lignocellulose-degrading bacteria.

There are many reports on microbial consortia degrading corn stover (Table 1). The best microbial consortia can degrade $62 \%$ of corn stover without pretreatment and $78 \%$ of corn stover pretreated with acid or alkali (Wongwilaiwalin et al. 2010; Zhang et al. 2018). Our results showed that the three microbial consortia $(\mathrm{M} / \mathrm{Q} / \mathrm{Y})$ degraded more than $60 \%$ of corn stover without pretreatment, and the highest degradation rate was $71.59 \%$ by Y3. This indicated that the microbial consortia from feces could degrade corn straw efficiently, and the microbial consortia from sheep feces were slightly better than others.

Microorganisms hydrolyze straw to monomeric sugars by cellulase. Cellulase is a multienzyme complex mainly including endo-glucanase, exo-glucanase, and $\beta$-glucosidase, which act synergistically during enzymatic hydrolysis (Saini et al. 2015). Endo-glucanase is the most important component of cellulase system (Zhang et al. 2019). Endo-glucanase (EC 3.2.1.4) can randomly cleave the internal beta-1,4-glycosidic bonds in amorphous regions of cellulose polymers. In this study, endo-glucanase was used as an important basis to judge the ability of cellulase. The results showed that liquid volume had a significant effect on endo-glucanase activity, and endoglucanase was closely related to degradation rate, which is supported by previous works (Takizawa et al. 2020; Wang et al. 2004). This indicated that the lower dissolved oxygen environment caused by a higher liquid volume promote the activity of anaerobic lignocellulose degrading bacteria.

There are few studies on the effect of liquid volume on microbial diversity. Our study showed that the liquid volume had a significant effect on the degradation rate but not on microbial diversity. Microbial diversity was not closely related to the degradation rate. This suggested that the lower dissolved oxygen environment caused by higher liquid volume mainly increased the degradation rate of corn straw by promoting microbial activity but not microbial diversity. Our study also revealed that the microflora source had a significant effect on microbial diversity but not degradation rate. This indicated that the species degrading corn straw may be diverse. However, a study revealed that the microflora source had a significant effect on degradation rate but not on microbial diversity (Wongwilaiwalin et al. 2013). Different conclusions on degradation rate might be due to the similarity of consortia sources. We have already discussed this point in the first paragraph of Discussion. Different conclusions on microbial diversity might be due to different domestication times. The domestication time of our microbial consortia was short (4-6 generations), while that of Wongwilaiwalin's was long (21-27 generations). With the extension of domestication time and convergence adaptation, the microbial diversity might be more similar. This also indicated that different spatiotemporal scales might lead to different conclusions. Wongwilaiwalin's conclusion might be of larger spatiotemporal scale, and ours might be of smaller spatiotemporal scale.

A few studies analyzed the bacterial composition of corn stover degrading microbial consortia by highthroughput sequencing technology. In this study, we showed that the three microbial consortia (M, Q, and $\mathrm{Y}$ ) of corn straw degradation were mainly composed of Firmicutes and Proteobacteria. The results were supported by some previous works (Feng et al. 2011; Hua et al. 2014; Yu et al. 2019). However, some reports also showed that the microbial consortia degrading corn stover were mainly composed of Proteobacteria and Bacteroidetes or Firmicutes and Bacteroidetes or Proteobacteria and Actinobacteria (Liu et al. 2010; Qiao et al. 2013). These differences may be caused by the different sources and culture conditions of the microbial consortia. The microbial consortia composed of Firmicutes and Proteobacteria 


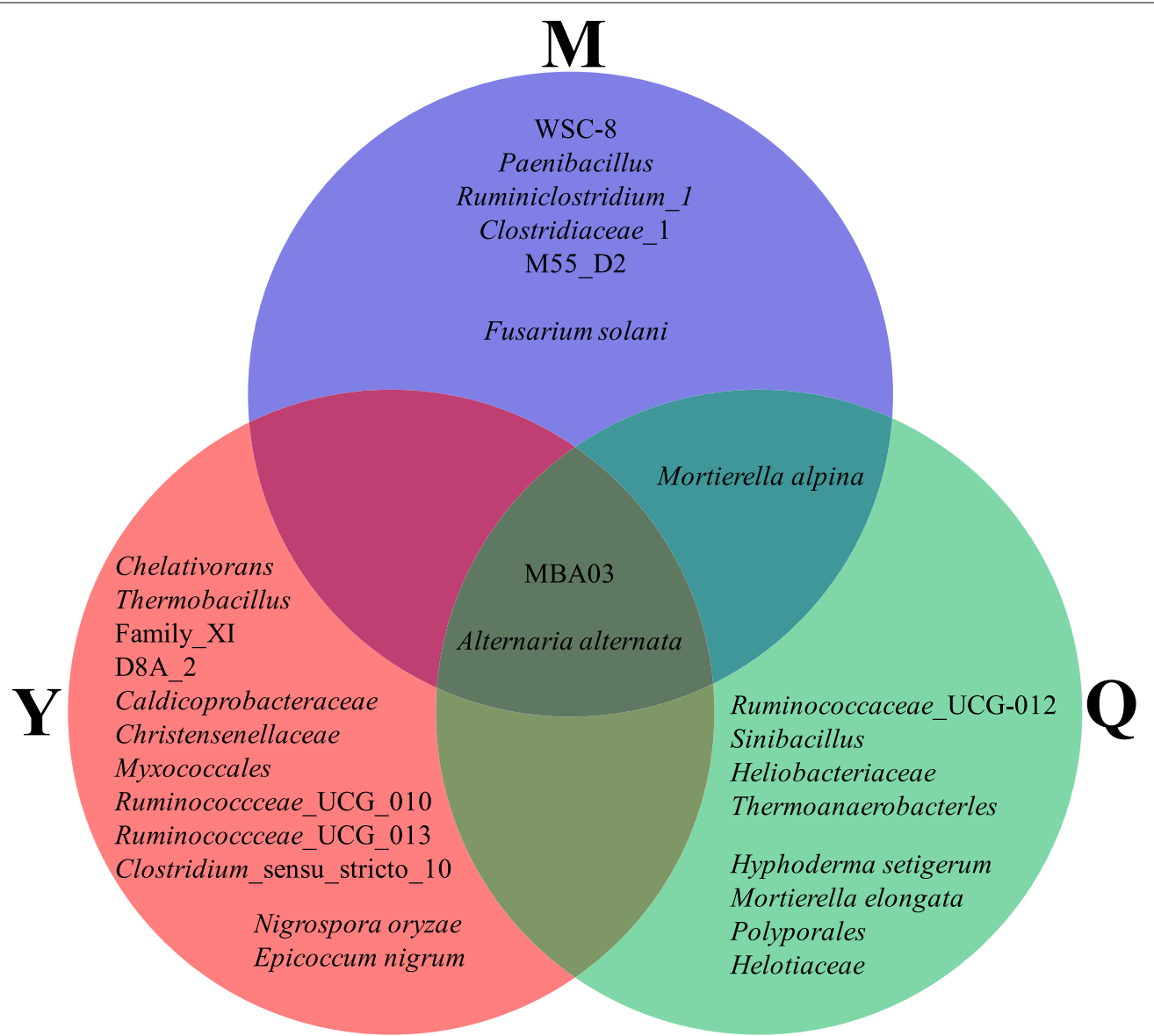

Fig. 6 Dominant and enriched species with a lignocellulosic degradation ability among the three bacterial communities. M, microbial consortia source from $\mathrm{MC1}$; $\mathrm{Q}$, microbial consortia source from $\mathrm{MC1}$, sheep, and cattle feces; $Y$, microbial consortia source from sheep feces

mainly came from feces and compost, and that composed of other bacteria mainly came from soil. Bacterial composition at the species level showed that most of the species in $\mathrm{M}, \mathrm{Q}$, and $\mathrm{Y}$ were unculturable bacteria. The dominant species in $\mathrm{M}, \mathrm{Q}$, and $\mathrm{Y}$ were significantly different. Uncultured_o_MBA03 was a common dominant species in $\mathrm{M}, \mathrm{Q}$, and $\mathrm{Y}$. MBA03 is often found in thermophilic anaerobic environments and may have a strong ability to degrade lignocellulose (Wu et al. 2020). Brevibacillus borstelensis, uncultured_Clostridia_WSC-8, unc ultured_Ruminiclostridium_1, and uncultured_Paenibacillus in M and uncultured_Ruminococcaceae_UCG-012 in $\mathrm{Q}$ have been reported to degrade lignocellulose (Liang et al. 2009; Mathews et al. 2016; Zhang et al. 2012).

Few studies have analyzed the fungal composition of corn straw degrading microbial consortia using highthroughput sequencing technology. This study showed that dominant fungi in $\mathrm{M}, \mathrm{Q}$, and $\mathrm{Y}$ were unclassified, Ascomycota, Zygomycota, and Mortierellomycota. Ascomycota and Zygomycota were also reported as dominant fungi in corn stover degrading microbial consortia
CCS-1 by a clone library (Liu et al. 2010). Fungal composition at the species level showed that most of the species in $\mathrm{M}, \mathrm{Q}$, and $\mathrm{Y}$ were unclassified, and the dominant species in $\mathrm{M}, \mathrm{Q}$, and $\mathrm{Y}$ were significantly different. Alternaria alternata, which is a common dominant species in $\mathrm{M}, \mathrm{Q}$, and $\mathrm{Y}$, has the ability to degrade cellulose and lignin (Guillen et al. 1987; Sharma et al. 2016). Fusarium solani in M, Mortierella elongata and Hyphoderma setigerum in Q, Nigrospora oryzae and Epicoccum nigrum in $\mathrm{Y}$ have been reported to have the ability to degrade lignocellulose (Lozovaya et al. 2006; Olajuyigbe et al. 2016; Yao et al. 2012; Yurchenko and Wu 2014).

The species enriched or inhibited by different microflora sources have close phylogenetic relationships, such as Paenibacillus enriched in M, Sinibacillus enriched in $\mathrm{Q}$, and Thermobacillus enriched in $\mathrm{Y}$ that all belong to Bacillales. M enriched Clostridiaceae_1, Ruminiclostridium_1, and M55_D21, Q enriched Heliobacteriaceae and Thermoanaerobacterles, and Y enriched Caldicoprobacteraceae, Christensenellaceae, Clostridium_sensu_stricto_10, Family_XI, 
Ruminococceae_UCG_010, Ruminococcceae UCG_013, and D8A_2, which all belong to Clostridia. It is speculated that the functions of these species in the three bacterial communities may be similar. Most of these species in Bacillales (Kong et al. 2020; Mathews et al. 2016) and Clostridia (Fosses et al. 2017; Meng et al. 2020) have stress resistance, such as high temperature and low dissolved oxygen resistance, and the potential for lignocellulose degradation. This was also supported by previous works that consortia originated from highly diverse environmental microflora sharing similar composite profiles at higher taxa levels with substantial differences at lower taxa levels (Wongwilaiwalin et al. 2013). In addition, $Q$ and $Y$ also enriched some thermophilic, anaerobic, or cellulolytic bacteria (Garcia and Müller 2020; Puig-Castellvi et al. 2020). Bacterial species enriched by L1 were mainly (facultative) aerobic bacteria (Van Craenenbroeck et al. 2011; Zotta et al. 2017), and most of these species cannot degrade cellulose. This indicated that the aerobic bacteria decreased significantly with the increase of liquid volume. The fungi enriched by $\mathrm{Q}$ were mainly from Ascomycota and Basidiomycota. Among them, some species in Polyporales and Helotiaceae have the ability to degrade lignocellulose (Gianoulis et al. 2012; Huang et al. 2019).

The dominant and enriched species with the lignocellulosic degradation ability among the three bacterial communities $(\mathrm{M} / \mathrm{Q} / \mathrm{Y})$ were sorted out (Fig. 6). It suggested that different microbial communities might degrade corn straw through different species combinations. Figure 3A showed that the distance between Q and $\mathrm{Y}$ bacterial community was close, and that between $\mathrm{Q}$ and $\mathrm{M}$ bacterial community was far. It was speculated that most of the bacteria in $\mathrm{Q}$ might originate from $\mathrm{Y}$. Figure $3 \mathrm{C}$ showed that the fungal communities of Q and Y3 are close, and Q was far away from other samples. It was speculated that most of the fungi in $\mathrm{Q}$ might originate from $\mathrm{N}$ (it was a pity that $\mathrm{N}$ samples with weak degradation ability were not reserved for microbial diversity detection), and some of them might originate from Y. However, Fig. 6 showed that $\mathrm{Q}, \mathrm{M}$ and $\mathrm{Y}$ shared less enriched species. It was speculated that when $\mathrm{M}, \mathrm{Y}$ and $\mathrm{N}$ were mixed into $\mathrm{Q}$, the complex interaction between species made their abundance changed significantly, resulting in that although the bacterial communities of $\mathrm{Q}$ and $\mathrm{Y}$ were similar, the enriched species were obviously different. The relationship between mixed microflora (e.g. Q) and source microflora (e.g. $\mathrm{M}, \mathrm{Y}$ and $\mathrm{N}$ ) is worthy of further study.

In conclusion, our results show that liquid volume had a significant effect on degradation rate while microflora source had a significant effect on microbial community in corn stover degradation.

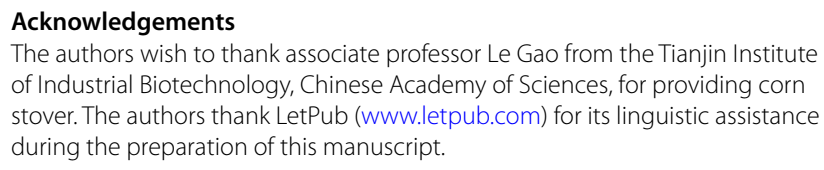
of Industrial Biotechnology, Chinese Academy of Sciences, for providing corn stover. The authors thank LetPub (www.letpub.com) for its linguistic assistance during the preparation of this manuscript.

\section{Authors' contributions}

JW and ZH designed research. DZ, JW, SZ and XZ performed the experiments. DZ, JW, SX, RY and WZ analyzed data. JW and DZ participated in writing the manuscript. All authors read and approved the final manuscript.

\section{Funding}

This work was supported by the National Key Research and Development Program of China [2018YFA0902200] and the Tianjin Synthetic Biotechnology Innovation Capacity Improvement Project [TSBICIP-PTJS-001].

\section{Aavailability of data and materials}

The raw sequence data reported in this paper have been deposited in the Genome Sequence Archive (Wang et al. 2017) in National Genomics Data Center (Zhang et al. 2020), Beijing Institute of Genomics (China National Center for Bioinformation), Chinese Academy of Sciences, under accession number CRA003666 that are publicly accessible at https://bigd.big.ac.cn/gsa.

\section{Declarations}

Ethics approval and consent to participate

Not applicable.

Consent for publication

Not applicable.

\section{competing interests}

The authors declare that they have no competing interests.

\section{Author details}

${ }^{1}$ Tianjin Key Laboratory for Industrial Biological Systems and Bioprocessing Engineering, Tianjin Institute of Industrial Biotechnology, Chinese Academy of Sciences, No. 32, West 7th Avenue, Tianjin Airport Economic Area, Tianjin 300308, P R China. ${ }^{2}$ National Technology Innovation Center of Synthetic Biology, Tianjin 300308, China.

Received: 7 April 2021 Accepted: 15 May 2021

Published online: 01 June 2021

\section{References}

Arntzen MO, Bengtsson O, Varnai A, Delogu F, Mathiesen G, Eijsink VGH (2020) Quantitative comparison of the biomass-degrading enzyme repertoires of five filamentous fungi. Sci Rep. https://doi.org/10.1038/ s41598-020-75217-z

Chu X, Awasthi MK, Liu Y, Cheng Q, Qu J, Sun Y (2021) Studies on the degradation of corn straw by combined bacterial cultures. Bioresour Technol 320:124174. https://doi.org/10.1016/j.biortech.2020.124174

Cui Z, Li M, Piao Z, Huang Z, Ishii M, Igarashi Y (2002) Selection of a composite microbial system MC1 with efficient and stability cellulose degradation bacteria and its function. Environ Sci 23:36-39

Deng B, Jia J, Ai S, Yan L, Gao Y, Wang Y, Wang W (2017) The screening and diversity of a bacterial community capable of degrading corn straw at 30 ${ }^{\circ} \mathrm{C}$. Renew Energ Resour 35:1127-1134

Ding CH, Wang X, Li MX (2019) Evaluation of six white-rot fungal pretreatments on corn stover for the production of cellulolytic and ligninolytic enzymes, reducing sugars, and ethanol. Appl Microbiol Biotechnol 103:5641-5652. https://doi.org/10.1007/s00253-019-09884-y

Feng YJ, Yu YL, Wang X, Qu YP, Li DM, He WH, Kim BH (2011) Degradation of raw corn stover powder (RCSP) by an enriched microbial consortium and 
its community structure. Bioresour Technol 102:742-747. https://doi.org/ 10.1016/j.biortech.2010.08.074

Fosses A, Mate M, Franche N, Liu N, Denis Y, Borne R, de Philip P, Fierobe HP, Perret S (2017) A seven-gene cluster in Ruminiclostridium cellulolyticum is essential for signalization, uptake and catabolism of the degradation products of cellulose hydrolysis. Biotechnol Biofuels. https://doi.org/10. 1186/s13068-017-0933-7

Garcia R, Müller R (2020) Metagenomic approach for the isolation and cultivation of cellulosedegrading myxobacteria. Philipp J Syst Biol. https://doi. org/10.26757/pjsb2020a14003

Gianoulis TA, Griffin MA, Spakowicz DJ, Dunican BF, Alpha CJ, Sboner A, Sismour AM, Kodira C, Egholm M, Church GM, Gerstein MB, Strobel SA (2012) Genomic analysis of the hydrocarbon-producing, cellulolytic, endophytic fungus Ascocoryne sarcoides. PLoS Genet. https://doi.org/10 1371/journal.pgen.1002558

Gong XJ, Zou HT, Qian CR, Yu Y, Hao YB, Li L, Wang QJ, Jiang YB, Ma JT (2020) Construction of in situ degradation bacteria of corn straw and analysis of its degradation efficiency. Ann Microbiol. https://doi.org/10.1186/ s13213-020-01601-9

Guillen F, Reyes F, Rodriguez J, Vazquez C (1987) Induction of an extracellular cellulase system during autolysis of Alternari alternata. Trans Br Mycol Soc 89:35-39. https://doi.org/10.1016/S0007-1536(87)80054-2

Haruta S, Cui Z, Huang Z, Li M, Ishii M, Igarashi Y (2002) Construction of a stable microbial community with high cellulose-degradation ability. Appl Microbiol Biotechnol 59:529-534. https://doi.org/10.1007/ s00253-002-1026-4

Hua BB, Lu Y, Wang JG, Wen BT, Cao YZ, Wang XF, Cui ZJ (2014) Dynamic changes in the composite microbial system MC1 during and following its rapid degradation of lignocellulose. Appl Biochem Biotechnol 172:951-962. https://doi.org/10.1007/s12010-013-0566-7

Huang L, Sun N, Ban LT, Wang Y, Yang HP (2019) Ability of different edible fungi to degrade crop straw. AMB Express. https://doi.org/10.1186/ s13568-018-0731-z

Kato S, Haruta S, Cui Z, Ishii M, Igarashi Y (2005) Stable coexistence of five bacterial strains as a cellulose-degrading community. Appl Environ Microbiol 71:7099-7106

Kong ZJ, Wang XQ, Wang MM, Chai LF, Wang XS, Liu DY, Shen QR (2020) Bacterial ecosystem functioning in organic matter biodegradation of different composting at the thermophilic phase. Bioresour Technol. https://doi. org/10.1016/j.biortech.2020.123990

Li X, Zhao XY, Yang JJ, Li SK, Bai SC, Zhao XY (2020) Recognition of core microbial communities contributing to complex organic components degradation during dry anaerobic digestion of chicken manure. Bioresour Technol. https://doi.org/10.1016/j.biortech.2020.123765

Liang JS, Nabi M, Zhang PY, Zhang GM, Cai YJ, Wang QY, Zhou ZY, Ding YR (2020) Promising biological conversion of lignocellulosic biomass to renewable energy with rumen microorganisms: A comprehensive review. Renew Sust Energ Rev. https://doi.org/10.1016/j.rser.2020.110335

Liang Y, Yesuf J, Schmitt S, Bender K, Bozzola J (2009) Study of cellulases from a newly isolated thermophilic and cellulolytic Brevibacillus sp strain JXL. J Ind Microbiol Biotechnol 36:961-970. https://doi.org/10.1007/ s10295-009-0575-2

Liu Y, Li L, Li J, Guan D, Jiang X, Shen D, Du B (2010) Construction and composition analysis of the complex microbial system CSS-1 of high decomposition efficiency for corn stalks. Sci Agric Sin 43:4437-4446

Lozovaya WV, Lygin AV, Zernova OV, Li S, Widholm JM, Hartman GL (2006) Lignin degradation by Fusarium solani f. sp. glycines. Plant Dis 90:77-82. https://doi.org/10.1094/PD-90-0077

Lu P, Li G, Chen L, Wang G, Wang X, Cui Z (2008) Influence of environmental oxygen concentration on cellulose decomposing ability by composite microbial system MC1. Trans Chin Soc Agric Eng 24:209-213

Mathews SL, Grunden AM, Pawlak J (2016) Degradation of lignocellulose and lignin by Paenibacillus glucanolyticus. Int Biodeterior Biodegrad 110:79-86. https://doi.org/10.1016/j.ibiod.2016.02.012

Meng XY, Yan J, Zuo B, Wang YH, Yuan XF, Cui ZJ (2020) Full-scale of composting process of biogas residues from corn stover anaerobic digestion: Physical-chemical, biology parameters and maturity indexes during whole process. Bioresour Technol. https://doi.org/10.1016/j.biortech. 2020.122742

Olajuyigbe FM, Nlekerem CM, Ogunyewo OA (2016) Production and characterization of highly thermostable beta-glucosidase during the biodegradation of methyl cellulose by Fusarium oxysporum. Biochem Res Int. https://doi.org/10.1155/2016/3978124

Puig-Castellvi F, Cardona L, Bouveresse DJR, Cordella CBY, Mazeas L, Rutledge DN, Chapleur O (2020) Assessment of the microbial interplay during anaerobic co-digestion of wastewater sludge using common components analysis. Plos ONE. https://doi.org/10.1371/journal.pone.0232324

Qiao JT, Guo RB, Yuan XZ, Shi XS, Xu XH, Fan XL, Qiu YL (2013) Phylogenetic analysis of methanogenic corn stalk degrading microbial communities. Environ Sci 34:1531-1539

Qinggeer, Gao J, Xiaofang Y, Zhang B, Wang Z, Naoganchaolu B, Shuping H, Sun J, Xie M, Wang Z (2016) Screening of a microbial consortium with efficient corn stover degradation ability at low temperature. J Integr Agric 15:2369-2379

Saini R, Saini JK, Adsul M, Patel AK, Mathur A, Tuli D, Singhania RR (2015) Enhanced cellulase production by Penicillium oxalicum for bio-ethanol application. Bioresour Technol 188:240-246. https://doi.org/10.1016/j. biortech.2015.01.048

Sharma A, Aggarwal NK, Yadav A (2016) First report of lignin peroxidase production from Alternaria alternata ANF238 isolated from rotten wood sample. Bioengineering Bioscience 4:76-87. https://doi.org/10. 13189/bb.2016.040502

Takizawa S, Asano R, Fukuda Y, Feng M, Baba Y, Abe K, Tada C, Nakai Y (2020) Change of dndoglucanase activity and rumen microbial community during biodegradation of cellulose using rumen microbiota. Front Microbiol 11:603818. https://doi.org/10.3389/fmicb.2020.603818

Tang Y, Fan Y, Zhu X, Hu H, Li H, Yao T (2020) Study on the selection and characteristics of CDS-10 for degradation of corn straw. Grassl Turf 4:80-91

Van Craenenbroeck AH, Camps K, Zachee P, Wu KL (2011) Massilia timonae infection presenting as generalized lymphadenopathy in a man returning to belgium from Nigeria. J Clin Microbiol 49:2763-2765. https://doi. org/10.1128/Jcm.00160-11

Wang C, Dong D, Wang H, Muller K, Qin Y, Wang H, Wu W (2016) Metagenomic analysis of microbial consortia enriched from compost: new insights into the role of Actinobacteria in lignocellulose decomposition. Biotechnol Biofuels 9:22-22

Wang D, Yao T, Yang Q, Han H, Zhang Y, Lu H, Gun S (2014) Screening and degradation characterization of efficient and stalbe cellulose degrading microbial communities. Acta Pratac sin 23:253-259

Wang J, Li Q, Xu S, Zhao W, Lei Y, Song C, Huang Z (2018) Traits-based integration of multi-species inoculants facilitates shifts of indigenous soil bacterial community. Front Microbiol. https://doi.org/10.3389/fmicb. 2018.01692

Wang W, Cui Z, Niu J, Piao Z, Liu J (2004) Construction of a composite microbial system of lignocellulose degrading and effect of cultural condition on the system capability. J China Agric Univ 9:7-11

Wang YQ, Song FH, Zhu JW, Zhang SS, Yang YD, Chen TT, Tang BX, Dong LL, Ding N, Zhang Q, Bai ZX, Dong XN, Chen HX, Sun MY, Zhai S, Sun YB, Yu L, Lan L, Xiao JF, Fang XD, Lei HX, Zhang Z, Zhao WM (2017) GSA: genome sequence archive. Genom Proteom Bioinf 15:14-18. https:// doi.org/10.1016/j.gpb.2017.01.001

Wongwilaiwalin S, Laothanachareon T, Mhuantong W, Tangphatsornruang S, Eurwilaichitr L, Igarashi Y, Champreda V (2013) Comparative metagenomic analysis of microcosm structures and lignocellulolytic enzyme systems of symbiotic biomass-degrading consortia. Appl Microbiol Biotechnol 97:8941-8954

Wongwilaiwalin S, Rattanachomsri U, Laothanachareon T, Eurwilaichitr L, Igarashi Y, Champreda V (2010) Analysis of a thermophilic lignocellulose degrading microbial consortium and multi-species lignocelluloIytic enzyme system. Enzyme Microb Technol 47:283-290. https://doi. org/10.1016/j.enzmictec.2010.07.013

Wu XY, Tian ZZ, Lv ZP, Chen ZX, Liu YD, Yong XY, Zhou J, Xie XX, Jia HH, Wei $P$ (2020) Effects of copper salts on performance, antibiotic resistance genes, and microbial community during thermophilic anaerobic digestion of swine manure. Bioresour Technol. https://doi.org/10.1016/j.biort ech.2019.122728

Xing BS, Cao SF, Han YL, Wang XC, Wen JW, Zhang KD (2020) A comparative study of artificial cow and sheep rumen fermentation of corn straw and food waste: Batch and continuous operation. Sci Total Environ. https://doi.org/10.1016/j.scitotenv.2020.140731 
Yao RS, Zhang P, Wang H, Deng SS, Zhu HX (2012) One-step fermentation of pretreated rice straw producing microbial oil by a novel strain of Mortierella elongata PFY. Bioresour Technol 124:512-515. https://doi. org/10.1016/j.biortech.2012.08.142

Yu X, Borjigin Q, Gao J, Wang Z, Hu S, Borjigin N, Wang Z, Sun J, Han S (2019) Exploration of the key microbes and composition stability of microbial consortium GF-20 with efficiently decomposes corn stover at low temperatures. J Integr Agric 18:1893-1904

Yuan X, Gao R, Li P, Zhu W, Wang X, Cui Z (2011) Improvment of anaerobic biogasification efficiency by pretreatment of corn straw with composite microbial system of MC1. Trans Chin Soc Agric Eng 27:266-270

Yurchenko E, Wu SH (2014) Hyphoderma pinicola sp nov of H-setigerum complex (Basidiomycota) from Yunnan. Bot Stud, China. https://doi.org/ 10.1186/s40529-014-0071-5

Zhang S, Xu Z, Wang T, Kong J (2019) Endoglucanase improve the growth of homofermentative Lactobacillus spp. in ensilages. J Biotechnol 295:55-62. https://doi.org/10.1016/j.jbiotec.2019.02.010

Zhang X, Qiu WH, Chen HZ (2012) Enhancing the hydrolysis and acidification of steam-exploded cornstalks by intermittent $\mathrm{pH}$ adjustment with an enriched microbial community. Bioresour Technol 123:30-35. https://doi. org/10.1016/j.biortech.2012.07.054

Zhang Y, Ji J, Guan C, Jin C, Li Q, Yan B, Wang G, Wang Y (2018) Screening of straw-degrading strains and their enzyme-producing conditions. J Cellul Sci Technol 26:28-38

Zhang YHP (2008) Reviving the carbohydrate economy via multi-product lignocellulose biorefineries. J Ind Microbiol Biotechnol 35:367-375. https:// doi.org/10.1007/s10295-007-0293-6

Zhang Z, Zhao WM, Xiao JF, Bao YM, He SM, Zhang GQ, Li YX, Zhao GP, Chen RS, Gao Y,Zhang C, Yuan LY, Xu SH, Ning ZL, Lu Y, Zeng JY, Yuan N, Zhu JW, Pan MY, Zhang H,Wang Q, Shi S, Jiang MY, Lu MM, Qian QH, Gao QW, Shang YF, Wang JY, Du ZL, Tian DM,Wang P, Tang BX, Li CP, Teng XF, Liu XN,
Zou D, Song SH, Xiong Z, Li MW, Yang F, Ma YK, Sang J, Li ZH, Li RJ, Wang ZH, Zhu QH, Li X, Zhang SS, Kang HL, Dong LL, Ying C, Duan GY, Li MH, Zhi XY, Ling YC, Cao RF, Jiang Z, Zhou HK, Lv DQ, Liu W, Klenk HP, Zhang YD, Zhang ZW, Chen TT, Chen X, Wang YQ, Wu S, Gong Z, Chen ML, Fang SS,Zhang LL, Guo JC, Niu YW, Wu Y, Li H, Zhao LH, Li XY, Teng XY, Sun XH, Sun L, Zhao Y, Wang JJ, Zhang P, Li YY, Zheng Y, Chen XM, Xue H, Teng YH, Kang Q, Hao YJ, Cao JB, Liu L, Li Z, Li QP, Du Q, Abbasi AA, Shireen H, Pervaiz N, Batool F, Raza RZ,Ma LN, Niu GY, Zhang YS, Zhu TT, Hao LL, Wang GL, Yan J, Li C, Wang ZN, Wang XF, Li ZH, Zhang Y, Wang HL, Zhang Y, Xia XL, Guo HW, Zhu JW, Zhou Q, Kang HG, Lan L, Zhang X, Xue YB, Sun YB, Zhai S, Yu L, Sun MY, Chen HX, Hu H, Guo AY, Lin SF, Xue Y, Wang CW, Ning WS, Zhang XX, Xiao Y, Li X, Tu YR, Wu WY, Ji PF, Zhao FQ, Luo H, Gao F, Guo YP, Yuan H, Zhang YE, Zhang Q, Zhou JQ, Huang Z, Cui QH, Miao YR, Ruan C, Yuan CH,Chen M, Jin JP, Tian F, Gao G, Shi Y, Yao L, Li XS, Li CY, Tang Q, Peng D (2020) Database resources of the national genomics data center in 2020. Nucleic Acids Res. https://doi.org/10.1093/nar/gkz913

Zhou Y, Pope PB, Li S, Wen B, Tan F, Cheng S, Chen J, Yang J, Liu F, Lei X (2015) Omics-based interpretation of synergism in a soil-derived cellulosedegrading microbial community. Sci Rep 4:5288-5288

Zotta T, Parente E, Ricciardi A (2017) Aerobic metabolism in the genus Lactobacillus: impact on stress response and potential applications in the food industry. J Appl Microbiol 122:857-869. https://doi.org/10.1111/jam. 13399

Zuroff TR, Curtis WR (2012) Developing symbiotic consortia for lignocellulosic biofuel production. Appl Microbiol Biotechnol 93:1423-1435. https://doi. org/10.1007/s00253-011-3762-9

\section{Publisher's Note}

Springer Nature remains neutral with regard to jurisdictional claims in published maps and institutional affiliations.

\section{Submit your manuscript to a SpringerOpen ${ }^{\odot}$ journal and benefit from:}

- Convenient online submission

- Rigorous peer review

- Open access: articles freely available online

- High visibility within the field

- Retaining the copyright to your article

Submit your next manuscript at $\boldsymbol{\nabla}$ springeropen.com 